\title{
Plan and Architecture of Patrimony House in Sulaymaniyah during the Ottoman Rule (Said Mutabjee House Pattern)
}

\author{
Dr. Haider Farhan AL-Subaihawi \\ Baghdad University/College of Arts
}

\begin{abstract}
The house is located south of the soapkran area, its One of the oldest residential areas in Sulaymaniyah, Which is part of the of "Quiza" province located in the center of the Sulaymaniyah city. has constructed by Haj Saeed Tutunji in the year of (1308 AH / $1891 \mathrm{AD})$ At end of Ottoman rule. It has a rectangular area of about $\left(820 \mathrm{~m}^{2}\right)$. The main materials used in the house construction are brick, plaster, wood and reed mats. The bricks used in the construction of the house walls, as well as in paving room floors, while plaster used as a bond between bricks rows, as well as in the walls and floors cladding. Wood was used in roofing, doors, windows, columns, windows, and Al-chenachel. The reason for this is a desire Iraqi architect to relieve the weight pressure on the ground floor walls.
\end{abstract}

Keywords: patrimony House, Ottoman rule, Sulaymaniyah, House Plan.

\section{Introduction}

Sulaymaniyah city is one of cities which has old history, Archaeological excavations revealed evidences of human settlement, since the Medieval Stone period. during the American expedition of excavations in the Hazmarred cave, which located about 18 kilometers south-west of the city, Musterian stone tools made by Neanderthal man at the in the lower layers of this cave were found.

During Ottoman rule, its establishment dates back to the Babani Emirate, in northern Iraq around the twelfth century $\mathrm{AH} /$ eighth century AD, the Babani Emirate was founded in the north-eastern part of Iraq, and has taken Joualan Castle as its center. In the year (1191 $\mathrm{AH} / 1778)$ was ruled by Mahmoud Pasha Baban, When he wanted to Support his influence and enforce his position, he established a fortified castle in the village of "Malakandi" , in the year of (1194 $\mathrm{AH} / 1781 \mathrm{AD}$ ). Which is today name is one of the known areas in Sulaymaniyah, The castle was the first official building built there, Two years later, when the emirate moved to Ibrahim Pasha bin Ahmed Pasha Baban, in order to strengthen the affairs of his property, he Built around the mentioned castle many houses, shops, a mosque and a bathroom in the Year (1197 AH / 1784 AD).

A field survey of the Patrimony buildings of $\mathrm{Al}-$ Sulaymaniyah Antiquities Department has conducted, and more than one hundred and six buildings were registered, The government was able to buy seventeen of them, as yet, Seven of them were restored, and the Haj Said Hema house, - the subject of research - was one of those buildings.

Site and history of the house: House is located South of Soapkran, which is one of the oldest residential areas in Sulaymaniyah, It is part of the Quiza province, lies in the Sulaymaniyah city center(map 1), Specifically, the house is located within the Building No. 465 , Built by Hajj Said Tuttenji(1308 AH / 1891 AD) at the end of Ottoman rule, Later, its ownership was transferred to Hajaj Said Hama Amin Mutabaji, Which has been decorated two rooms on the top floor with various decorations, later, Will be discuss about it.

House Planning: Total house area is $\left(820 \mathrm{~m}^{2}\right)$, its rectangular shape has a main entrance lies in the southwest corner, (Scheme No.1), and later was filled, and Part of the park is still prominent, Despite many abuses and divisions Which took place (Photo 1), After the large garden, the house built on a rectangular area of $\left(189 \mathrm{~m}^{2}\right)$, The house front length is $(21 \mathrm{~m})$, house has depth about $(9 \mathrm{~m})$, and height $(5,90 \mathrm{~m})$ It consists of a ground and an upper floors(Plan No2).

The house front façade was built by square bricks and the plaster which used as a bond between bricks rows. The bricks rows are arranged in different horizontal and vertical positions which is composed of a type of bricks decoration. façade is divided into three parts, the middle is the main one, It is designed in Euan, rising up the two floors, and from the top ends in tapered arch, The door is topped by a semicircular arch, which was probably a stained glass window, do not know about door made, Whether it be wood or other material, Due to changes in the construction as well as considerable damage due to the aging of the time and the use of its residents without maintenance until recently. It is believed that the original door was made of wood and consists of two shutter, It is since the fourth century AH / 10th century AD, The houses doors were made of wood and decorated with engravings, In all Iraqi cities, with one or two shutters and some of them decorated with various decorations. There are some wooden doors inlaid with other wood of different colors dominated by black color as in the house of Rashid Aga in Erbil. The current door is iron made, The stairs consist of eleven steps, built of bricks and plaster, lead to the top floor, a terrace On both sides of stairs is a brick-built, used to sit, It is known that such a terrace was not a new phenomenon in Iraqi houses, Where they were existed outside the entrances of houses in the Islamic period, As in the houses of Samarra and other Iraqi cities. (Photo2 and Scheme No2). 


\section{International Journal of Science and Research (IJSR) \\ ISSN (Online): 2319-7064}

Index Copernicus Value (2015): 78.96 | Impact Factor (2015): 6.391

Both sides of the outer façade had a door for each, Leads to inside each wing of them On the ground floor, These doors are topped by a semi-cylindrical arch, In addition to rectangular windows, their tops have semi-cylindrical from,(Photo3 and Scheme No3). These windows are covered and decorated with stained glass, Which is still visible in the upper floor windows, (Photo 4) While the arches above the ground floor windows were removed, and filled with bricks and plaster at a later time From the construction date, Where the remains of those contracts are still present. A fixed window known as the lunar, and is above the doors and windows or higher walls, Is, of course, an ideal environmental treatment , We do not expect these "lunar" windows to provide air into the rooms because they are a fixed window that can not be opened and closed when needed but is always closed.

But its function is to control with light amount which enter the rooms, and protects the interior spaces from direct exposure to sunlight, as well as reduce the light amount which comes inside the place. cooler glass reduces the intensity of light rays, As well as finding some kind of satisfaction when considering light that enters, Whether it is daylight sunlight or moonlight at night, Which reflects multiple colors on the window, then, Two purposes are obtained at the same time, Environmental purpose and light control. The ground floor is consists of a long corridor, It can be said that it represent a distribution room, which through it could see all house

Sections, and this system is known in Iraqi architecture since ancient times such as of Sippar and Ur Houses in the old Babylonian period, As well as in the first and second layers of the Zabalam site, which belong to old Babylonian period. The distribution room divided the house into two wings which are not equal in length (Scheme 4), The western wing to the right of stairs is 7,25 $\mathrm{m}$ (map no.5), It contains two rooms that are located on one equalization, Front (R1.5) is rectangular and its dimensions are $(6,45 \mathrm{~m} \times$ $3,80 \mathrm{~m})$, Can be through it by outer entrance, is Consists of one shutter, has four rectangular windows overlooking the garden, Its floor is paved with square bricks (Figs.5 and3). Well known back room(R1.6) is the smaller and rectangle in shape, with dimensions $(6,45 \mathrm{~m} \times 2,80 \mathrm{~m})$, It shares with front room through single overlooking it entry, its floor is also paved with square bricks, and is currently destroyed and its roof is collapsed (Fig. 6).

The east wing is located to the left of the stairs Length (11 m) (Chart No.5), It contained three rectangular rooms, two of them are lies one straightness, the front is (R1.2) with dimensions $(5,80 \mathrm{~m} \times 3,80 \mathrm{~m})$, its floor is also paved with square bricks, (Fig.7). The rear room (R1.3) was of $(5,80 \mathrm{~m} \times 2,80 \mathrm{~m})$ and its floor was paved with square branches (Fig. 8). The third room (R1.4) is located along the two rooms together and perpendicular to them, with dimensions of $(7,40 \mathrm{~m} \times 3,80 \mathrm{~m})$, It has one entrance lies in the middle of its western wall and opened for two rooms, One large and rectangular window overlooking the outside, We believe that its floor was paved with square bricks like other rooms, However, they were removed at a later time and replaced with a cement pavement (Figure 9).
The upper floor is completely separated from the ground one, Each floor seems to be an independent building unit of the other, Where access to the upper floor from the outside, because no interior stairs from inside, in usual, that in the Iraq's northern regions, The ground floor is reserved for the house owners, While the upper floor is isolated and reserved for guests, The view is supported by the fact that walls and ceilings of upper floor rooms have their decorations, and the other rooms on the ground floor, are emptied, People are still following this tradition In paying attention to guests places in Iraqi patrimony houses, As well as isolating the floors of each other maintains good temperatures for each floor especially in the winter, which is characterized by extreme cold.

Generally, is no much different between the upper floor accessed by an outer stairs and the ground floor, Because of the wide similarity between them, The room measurements are similar to those at ground floor, because the walls of the second floor were directly built on the walls of the ground floor. Except for a slight alteration in the eastern wing where an open balcony was designed instead of the room below it on the ground floor (Schemes 6 and 7), Therefore, this floor is consists of a distribution room which comes immediately after the entrance then a small $\operatorname{room}(\mathrm{R} 2.5)$, Its walls contained some rectangular spaces(Kuwa) its current pavement damaged and paved with cement (Photo 10), then, the two rooms of western wing, which corresponds by space and design with two rooms below them except that the front room entrance (R2.7) which lies to the east side and other overlooking distribution room, which is characterized by their Niches and verity of its walls and ceiling decorations (picture11). a large part of rear room (R2.6) was destroyed, However, we can distinguish some Niches in their walls, (Photo 12).

The east wing of this floor consists of a front balcony, based on two columns(R2.2 ),(Picture 13), The current columns are made of iron, and perhaps the original columns were wood made, In order to reduce the weight placed on the roof of the ground floor and it walls, The balcony contained a stairs that led us to the upper floor roof, Which contains a small room that is used as a store for household items(Picture 14), which is well known in Iraq as "Batonah". The definition given by Twaini as: A small store at upper house where the bedding is kept, In the summer day, At night they took them out for sleep, Directly behind the balcony is a rectangular room with the same measurements as the room below, which it walls included some Niches (Fig. 15). Currently, its floor is covered with cement, then Orthopedic room to it (R2.3), It has measurements of the room directly below it, This room feature is full of decorations and many niches, The room indicates that it is divided into two parts because of a semicircular arch that holds ceiling in the mid of room, These cases are common in Iraqi architecture and aim to strengthen the walls and help reduce the weight of the weight, This room is characterized also by retaining some of its paved floors with square bricks(Fig. 16). This gives us an impression that the floors of the upper floor have been paved with bricks too, such as in the ground floor, but it was lifted and replaced with concrete cement in the building later. 


\section{International Journal of Science and Research (IJSR) \\ ISSN (Online): 2319-7064}

Index Copernicus Value (2015): 78.96 | Impact Factor (2015): 6.391

It is important to note that walls were coated with plaster in order to make them more smoothness and acceptable, The rooms on the upper floor were characterized by a large number of niches, which were used as shelves to put some antiques on them or to save some of the necessary requirements, or to put lighting such as lamps, As well as easing the wall weights on the upper floor, The use of niches has appeared in the ancient Iraqi architecture, which was discovered through Iraqi archaeological excavations in the first layer of Tell el-Sawan, which dates back Hassouna period, in the middle of one of the room walls, a niche was discovered, Where under the top soil, a marble statue of the mother goddess was found, And continued until the Islamic times, where was revealed in the Kufa Emirate three small niches (14), As a result of the multiple use of them, We note that they are extremely used in the Iraqi house inside the rooms, In a single or double row one above each other, and this is what is noticed in Dar Said Muti Abji - in this research. The house exterior and interior walls are thick, Approx. $(80 \mathrm{~cm})$ (plan No. 8), which is a known feature in Iraqi ancient architecture, and continued to be used in Islamic times, Implemented in environmental treatments access. Walls are the most important building joints as they going to strength of construction and the ability of endurance, ceilings carry and prevent the entry of dust and wind, and then divide into acceptable spaces can be used and, and is a barrier voice and heat(17).

The room ceilings on the ground and upper floors were of known as al- Quawag wood And mats, the wood staff are lined horizontally above the walls in equal spaces between the one and the other, and then covered by mats, Then clay will mix with straw or plaster that was used extensively in later periods of Ottoman period, for the purpose of disposal of spaces and prevent the leakage of rain water or the entry of dust from the spaces to the rooms, this type of roof was used in several areas of Iraq and since early periods, Some old Muslim historians mentioned its use During the early Islamic period. Hirtsfeld mentioned that the Great Mosque roofs in Samarra were covered with palm trunks, and with a thick of mud, Buckingham, who visited Basra during the Ottoman rule, referred to the people's use of palm trees in roofing(20). Often, most of room ceilings have secondary ceilings made of wooden panels, The secondary ceilings in guest rooms are decorated with different types of decoration (21), The spaces between the panel and the other are covered with thin wooden panels known as "Traish", In the middle of each room ceiling, a beautiful geometric shape is placed and consisting of color glass and mirror peaces, Called "ganga", a chandelier was hang in its middle(22). The exact case is similar to Mr. Mutabegi's house, which we noted the upperfloor of gust rooms ceilings are decorated, currently, There are no secondary ceilings for house of ground floor, because the secondary roof is covered with metal panels known as' Ginko',

It is a Turkish word meaning the metal known as tin or zinc, has other uses (23),

We believe that the ceilings of the ground floor rooms were also covered with a secondary roof of the wood layers, but are not likely to be decorated because there is no evidence to prove this, So we exclude that the ceilings of the ground floor are decorated with a kind of decoration.

\section{Building Materials}

The main materials were used in the house construction are bricks, plaster, wood and mats - as we have pointed out -,

Bricks were used in the house walls construction, which is one of the oldest materials known and used by people, which made of clay, It is strong and resistant to climate change (24). It is characterized by durability, regularity of the edges and high portability of heavy loads and high pressure, so, were widely used (25). Plaster was used as a bond between the bricks rows and in walls and floors covering, and reason for use this material is obtainable,hardening quick and easy preparation from an extractor, when burning, does not require high temperature, its bond material, stronger than clay, and it has climate resistance(26).

Wood is one of the most important materials used in houses building since ancient times, It used in roofing and manufacturing doors, windows, columns and niches, The reason is Iraqi architect desire to ease the walls weight on the ground floor, Despite its extensive use in construction, but Wood is one of the main buildings weaknesses, especially if it is a major construction material, because its resistance weak for several properties such as moisture, salts and rodents(27), then, reeds used in ceilings covering since ancient periods in Mesopotamia till the Ottoman time, Where the Great Mosque roofs in Samarra were covered with palm tree trunks, and above the trunks are reeds layer and mud(30)

\section{The Decorative Elements}

The Ottoman buildings were decorated only from inside, Except for some part over doors and windows(31), and this is what we have noticed in the Mutabaji House - the subject of research -, The owner was cared for interior house decoration, In the walls and ceilings of the rooms are especially those reserved for guests, while Outside the house is almost empty except for decoration at top floor entrance.

Through our study of the motifs of Mutabegi house, we noticed that the facade exterior decoration of the house was carried out on the bricks (Picture 2), As well as in the inside of the pointed arch, that rises above the upper floor entrance (Photo 17), Where the difference positions of vertical and horizontal bricks resulted palm tree form, alternately between the head and the base or the forms of the object when they meet. The rows of horizontal and vertical bricks alternately emerged through the use of pink and yellow, which showed Exquisite appearance, This type of geometric ornamentation is probably one of the simplest types of geometric ornamentation, which is based on the advantage of the rectangular shape of brick itself in order to form geometric forms resulting from the difference in the position of bricks, in most of frescoes that we received was appear from Baghdad, most notably the decoration of minarets and the tomb of zumarrad Khatoun and Khan Morgan(32). 


\section{International Journal of Science and Research (IJSR) \\ ISSN (Online): 2319-7064}

Index Copernicus Value (2015): 78.96 | Impact Factor (2015): 6.391

The interior decoration was carried out on gypsum, glass, mirrors, wood. generally, The engineering elements in Islamic art were adopted. The wall frescoes that filled the walls top contained sometimes, With prominent and precise plant motifs within geometrical frames, Wavy twigs, branches of which are triangular leaves, Multi-head ribbons (Picture 18), These models were widespread during the Ottoman rule and were mixed with the prevailing local character, In the Islamic world centers which were belong to Ottoman rule such as Iraq, Egypt, Damascus, Tunisia and Algeria(33)

The colored and un colored mirror were used in Gypsum decoration, The colored mirrors were used as frames surrounded by stucco motifs (Figs.16 and 19), and formed geometric shapes such as triangles or undulating lines, Through the use of more than one color in the implementation of those decorations, While the non-colored mirrors were used in the formation of other decorative artistic elements, including the element of the candlestick, Or floral element (Fig. 16), Mirrors help to illuminate the interior of the room through reflected light.

The wood decorations which done for rooms' ceilings were geometrical, Where the wooden secondary ceiling was divided into rectangles, each of one had irregular shape (Picture 20), This geometric element is used in most artistic works as frames with other decorative elements inside it, or as a main element in the decorative theme, Which we found a lot decorating residential houses in the city of Mosul, It was once in the form of sequential objects were emptied from decoration - as in the house of Mutabegi - and sometimes appears in a frame inside it a rose, Or inside it another geometric element such as the circle(34).

\section{Conclusions}

From our study to Mr. Mutabji 's house we conclude That an architecture tried to make a suitable house for the climatic positions which characterize the mountainous region in the northern of Iraq, So there is no open courtyard surrounded the rooms Which we find within the planning characteristics of house in central and southern part of Iraq, Where temperatures is high in summer and down in winter, Thus, they are similar in terms of planning with the closed Seljuk architecture in Anatolia, Which has not central courtyard, If its existed, it is only a small yard, and this architectural planning is consistent with the climate's coolness (35). Another characteristic is that house floors are almost separated, There is no drawer inside the house where you can move up to the top floor, This planning is different from houses in central and southern Iraq The similarity between the house in Sulaymaniyah and the houses in central and southern Iraq is Use the same building materials, and similarity of room decorations.

\section{Recommendations}

Heritage should be taken as an important and vital part of Iraq's cultural heritage and legislation to prevent its destruction and alter its urban fabric under the pretext of modernization .
Restoration and rehabilitation of heritage buildings in the governorates such as schools, schools, bathrooms and others to be local architectural models for the definition of future generations.

\section{Margins}

[1] Dabbagh, Taqi, "Iraq in Prehistoric Times," Iraq in History, Baghdad, 1983, p. 50.

[2] Matar, Salim others , Encyclopedia of Iraqi Cities, Baghdad, 2005, p. 244.

[3] According to official statistics from the Department of Antiquities of Sulaymaniyah.

[4] Metz, Adam, The Islamic Civilization in the 4th Century AH, Translated by: Muhammad Abdul Hadi Abu Rida, Beirut, 1967, 1, p. 221.

[5] Daraji, Hamid Mohammed Hassan, The Iraqi House in the Ottoman Period Architectural and Decorative Elements, Baghdad, 2008p. 2, p.212

[6] Directorate of Ancient Antiquities, Samarra Excavations 1936-1939, Baghdad, 1940, p1, p. 31.

[7] Waziri, Yahya, Islamic Architecture and the Environment, The World of Knowledge, Kuwait, 2004, p. 126

[8] Al-Qaisi, Kahlan Khalaf, The Iraqi House in the Early Babylonian Period in the Light of Spar Excavations, Unpublished Master Thesis Submitted to the Council of the college of Arts, University of Baghdad, 1989, p 194.

[9] Al-Subaihawi, Haider Farhan Hussein, "Archaeological Excavations at Bazikh for the First and Second Periods", Sumer Journal, Baghdad, 2003-2004, Vol. 52, p1\& 2, p.174

[10] Daraji, Hamid Mohammed Hassan, the Iraqi House in the Ottoman Period Architectural and Decorative Elements, Baghdad, 2008,p 1, p. 32

[11] Thawini, Ali, Dictionary of the Architecture of Islamic Peoples, House of Wisdom, Baghdad, 2005, p. 182.

[12]Al-Qusairi, Etmad Yusuf, The Planning and Architectural Characteristics of the House of Baghdadi during the Ottoman Period, Baghdad, 2012, p.15

[13] Gargis, Muwafaq, Iraqi House Building in Prehistoric Times, Unpublished Master Thesis, Introduction to the Council of the College of Arts, University of Baghdad, 1976, p. 166

[14] Al-Janabi, Kazem, Planning of the City of Kufa, Baghdad, 1967, p.39

[15] Makiya, Muhammad, "The Baghdad Role and the Residential Heritage", Baghdad Historical Illustrated Exhibition, Baghdad, 1969, p. 288.

[16] Al-Subaihawi, Haider Farhan Hussein, The Planning and Physical Processes of the Natural Environment in the Arab Islamic City of Iraq until 656 AH / 1258 AD, Unpublished Dissertation, submitted to the Council of the College of Arts, University of Baghdad, 2014, p 192.

[17] Al-Dawaf, Yusuf, Building construction and Building Materials,ed 3, Baghdad, 1969, p.54

[18] Al-Baladari, Ahmad ibn Yahya ibn Jabir (d. 279 AH / 892 CE), Fattouh al-Baladin, Salah al-Din al-Munajjid, Cairo, 1965, p. 2, p.347

[19] Daraji, Iraqi House, p. 2, p. 219.

[20] Buckingham, James, My trip to Iraq in 1816, translated by: Salim Taha al-Tikriti, Baghdad, 1968, p1, p. 262.

[21] Al-Qasiri, Planning Characteristics, p.49

\section{Volume 6 Issue 7, July 2017 www.ijsr.net}




\section{International Journal of Science and Research (IJSR) \\ ISSN (Online): 2319-7064}

Index Copernicus Value (2015): 78.96 | Impact Factor (2015): 6.391

[22] AL-Hjea Aziz Jassim, Baghdadiat, Freedom House for Printing, Baghdad, 1985, p. 2, p. 22.

[23] Bazarkan, Raouf Raafat, dictionary of exotic words in the Iraqi dialect, Baghdad, 2000, p. 65.

[24] Tamimi, Abbas Ali, the focus of the brick industry in Baghdad, Baghdad, 1976, p.9

[25] Al-Yawar, Talaat Rashad, "The climate and its impact on the art of building in archaeological architecture", Seminar on Architecture and Environment, Iraqi Academy of Sciences, Baghdad, 2003, p.19

[26] Bkaeen Hana "The Environment and Behavior of Some Structural Materials", Seminar on Architecture and Environment, Iraqi Academy of Sciences, Baghdad, 2003, p. 44.

[27] Dulaimi, Adel Abdullah, "Major Building Materials in Ancient Iraqi Architecture", Seminar of the Center for the survivals of Arab Scientific Heritage, University of Baghdad, 1990, p. 120.

[28] Abdul Razzaq, Saadi Faydi, "The Stages of Development of Structural Materials in Old Iraq", Al Ajyal Journal, Baghdad, 1981, p. 4, p. 216.

[29] AL-Ameed Taher Muzaffar, Baghdad, Al-Mansour AlRounded City, Najaf, 1967, p. 244.

[30] Daraji, Iraqi House,p 2, p. 219.

[31] Darraji, Iraqi House,p 2, p. 108.

[32] Al-Adhami, Khalid Khalil Hamoudi, wall decorations in the ruins of Baghdad, Baghdad, 1981, p. 132.

[33] Allam, Nemat Ismail, The Arts of the Middle East in the Islamic Ages, Cairo, 1974, p. 226.

[34] Abo, Muhammad Khader Mahmoud, Residential Architecture in the City of Mosul during the Eighteenth and Nineteenth Centuries of the Ottoman Period, unpublished doctoral thesis submitted to the Council of the Faculty of Archeology, University of Mosul, 2015, p. 156

[35] AL-Ameen , Salwa Ibrahim Tawfiq, Planning of the Seljuk Msjed and its Impact on the Planning of the Msajed of Iraq, unpublished Master Thesis submitted to the Council of the College of Arts, University of Baghdad, 2014, p.157

\section{References}

[1] Al-Adhami, Khalid Khalil Hamoudi, wall decorations in the ruins of Baghdad, Baghdad, 1981

[2] AL-Ameen, Salwa Ibrahim Tawfiq, Planning of the Seljuk Msjed and its Impact on the Planning of the Msajed of Iraq, unpublished Master Thesis submitted to the Council of the College of Arts, University of Baghdad, 2014.

[3] Bazarkan, Raouf Raafat, dictionary of exotic words in the Iraqi dialect, Baghdad, 2000.

[4] Bkaeen Hana "The Environment and Behavior of Some Structural Materials", Seminar on Architecture and Environment, Iraqi Academy of Sciences, Baghdad, 2003.

[5] Buckingham, James, My trip to Iraq in 1816, translated by: Salim Taha al-Tikriti, Baghdad, 1968, p1.

[6] Al-Baladari, Ahmad ibn Yahya ibn Jabir (d. 279 AH / 892 CE), Fattouh al-Baladin, Salah al-Din al-Munajjid, Cairo, 1965, p. 2.

[7] Tamimi, Abbas Ali, the focus of the brick industry in Baghdad, Baghdad, 1976.
[8] Thawini, Ali, Dictionary of the Architecture of Islamic Peoples, House of Wisdom, Baghdad, 2005.

[9] Gargis, Muwafaq, Iraqi House Building in Prehistoric Times, Unpublished Master Thesis, Introduction to the Council of the College of Arts, University of Baghdad, 1976.

[10] Al-Janabi, Kazem, Planning of the City of Kufa, Baghdad, 1967.

[11] AL-Hjea Aziz Jassim, Baghdadiat, Freedom House for Printing, Baghdad, 1985, p. 2.

[12] Dabbagh, Taqi, "Iraq in Prehistoric Times," Iraq in History, Baghdad, 1983.

[13] Directorate of Ancient Antiquities, Samarra Excavations 1936-1939, Baghdad, 1940.

[14]Daraji, Hamid Mohammed Hassan, the Iraqi House in the Ottoman Period Architectural and Decorative Elements, Baghdad, 2008,p 1.

[15] Daraji, Hamid Mohammed Hassan, The Iraqi House in the Ottoman Period Architectural and Decorative Elements, Baghdad, 2008,p2 .

[16] Al-Dawaf, Yusuf, Building construction and Building Materials,ed 3, Baghdad, 1969.

[17] Dulaimi, Adel Abdullah, "Major Building Materials in Ancient Iraqi Architecture", Seminar of the Center for the survivals of Arab Scientific Heritage, University of Baghdad, 1990.

[18] Al-Subaihawi, Haider Farhan Hussein, "Archaeological Excavations at Bazikh for the First and Second Periods", Sumer Journal, Baghdad, 2003-2004, Vol. 52, p1\& 2 .

[19] Al-Subaihawi, Haider Farhan Hussein, The Planning and Physical Processes of the Natural Environment in the Arab Islamic City of Iraq until 656 AH / 1258 AD, Unpublished Dissertation, submitted to the Council of the College of Arts, University of Baghdad, 2014.

[20] Abdul Razzaq, Saadi Faydi, "The Stages of Development of Structural Materials in Old Iraq", Al Ajyal Journal, Baghdad, 1981.

[21]Abo, Muhammad Khader Mahmoud, Residential Architecture in the City of Mosul during the Eighteenth and Nineteenth Centuries of the Ottoman Period, unpublished doctoral thesis submitted to the Council of the Faculty of Archeology, University of Mosul, 2015.

[22] Allam, Nemat Ismail, The Arts of the Middle East in the Islamic Ages, Cairo, 1974.

[23] AL-Ameed Taher Muzaffar, Baghdad, Al-Mansour AlRounded City, Najaf, 1967.

[24]Al-Qusairi, Etmad Yusuf, The Planning and Architectural Characteristics of the House of Baghdadi during the Ottoman Period, Baghdad, 2012.

[25] Al-Qaisi, Kahlan Khalaf, The Iraqi House in the Early Babylonian Period in the Light of Spar Excavations , Unpublished Master Thesis Submitted to the Council of the college of Arts, University of Baghdad, 1989.

[26] Metz, Adam, The Islamic Civilization in the 4th Century AH, Translated by: Muhammad Abdul Hadi Abu Rida, Beirut, 1967.

[27] Matar, Salim others , Encyclopedia of Iraqi Cities, Baghdad, 2005.

[28] Makiya, Muhammad, "The Baghdad Role and the Residential Heritage", Baghdad Historical Illustrated Exhibition, Baghdad, 1969. 


\section{International Journal of Science and Research (IJSR) \\ ISSN (Online): 2319-7064}

Index Copernicus Value (2015): 78.96 | Impact Factor (2015): 6.391

[29] Waziri, Yahya, Islamic Architecture and the Environment, The World of Knowledge, Kuwait, 2004.

[30] Al-Yawar, Talaat Rashad, "The climate and its impact on the art of building in archaeological architecture", Seminar on Architecture and Environment, Iraqi Academy of Sciences, Baghdad, 2003.
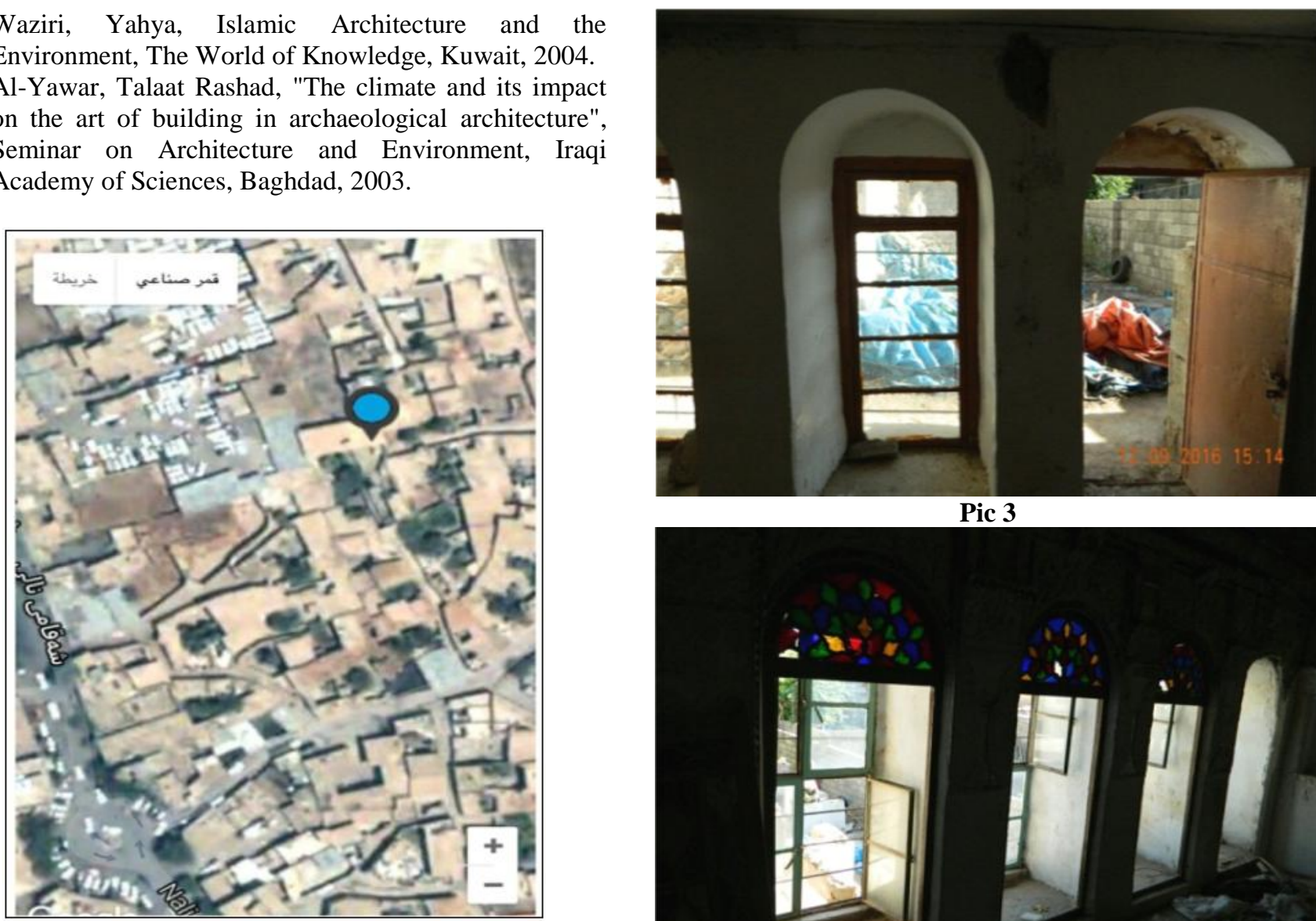

Pic 3

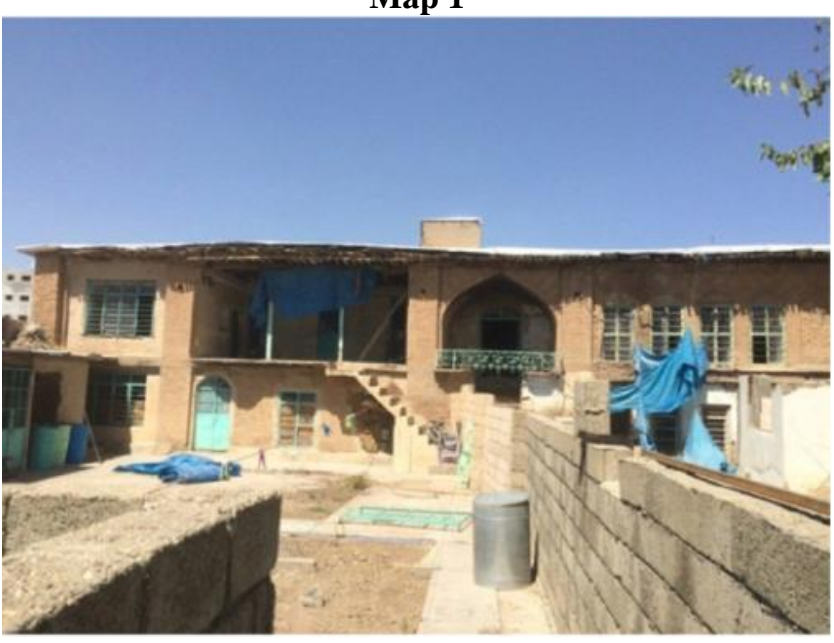

Pic 1
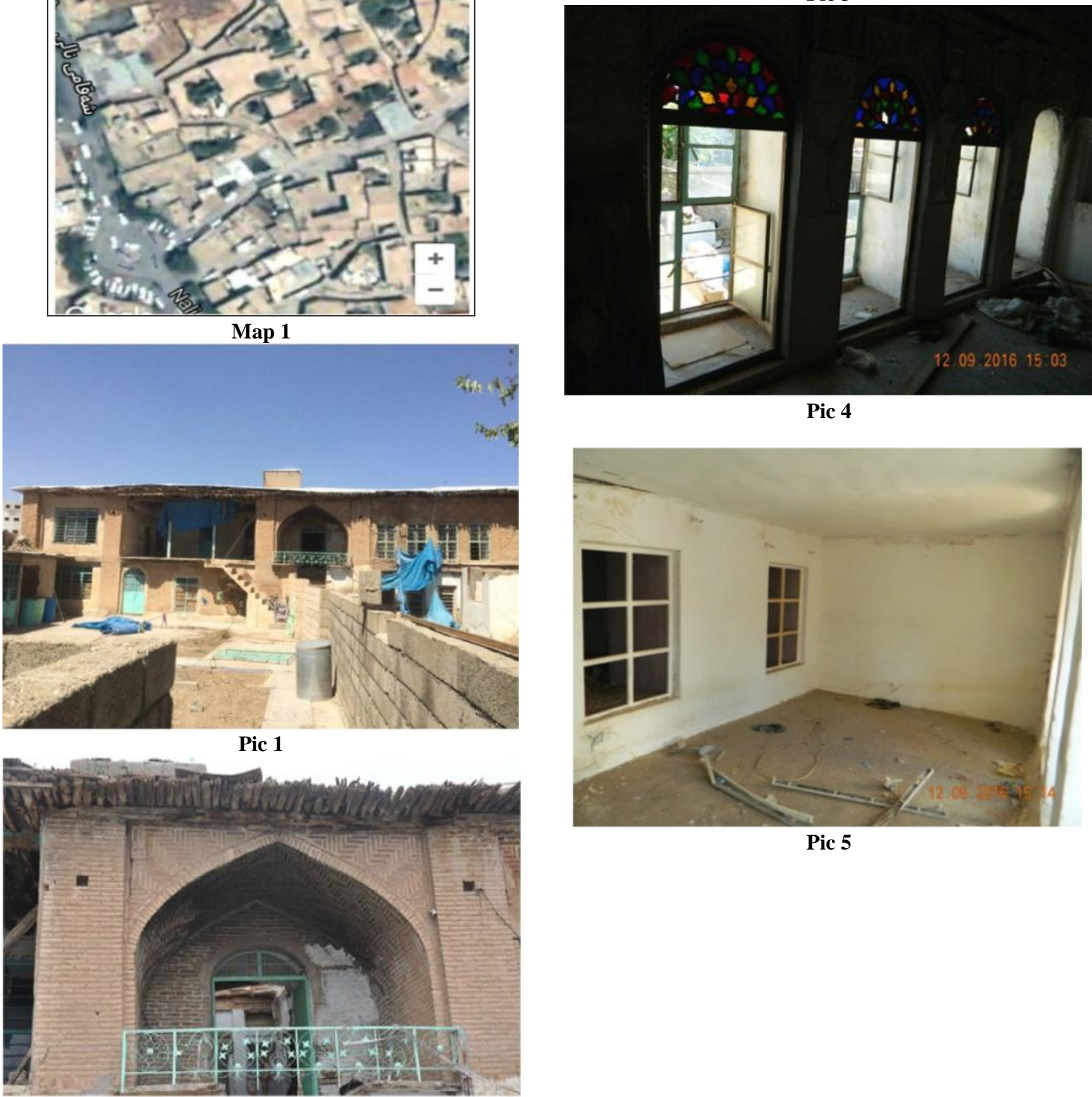

Pic 4

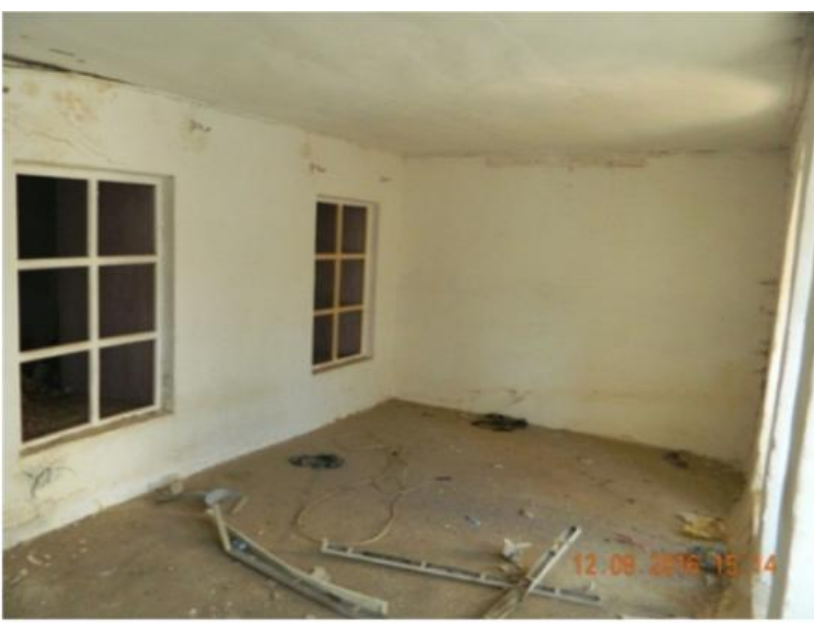

Pic 5

Pic 2

Volume 6 Issue 7, July 2017

www.ijsr.net

Licensed Under Creative Commons Attribution CC BY 
International Journal of Science and Research (IJSR)

ISSN (Online): 2319-7064

Index Copernicus Value (2015): 78.96 | Impact Factor (2015): 6.391

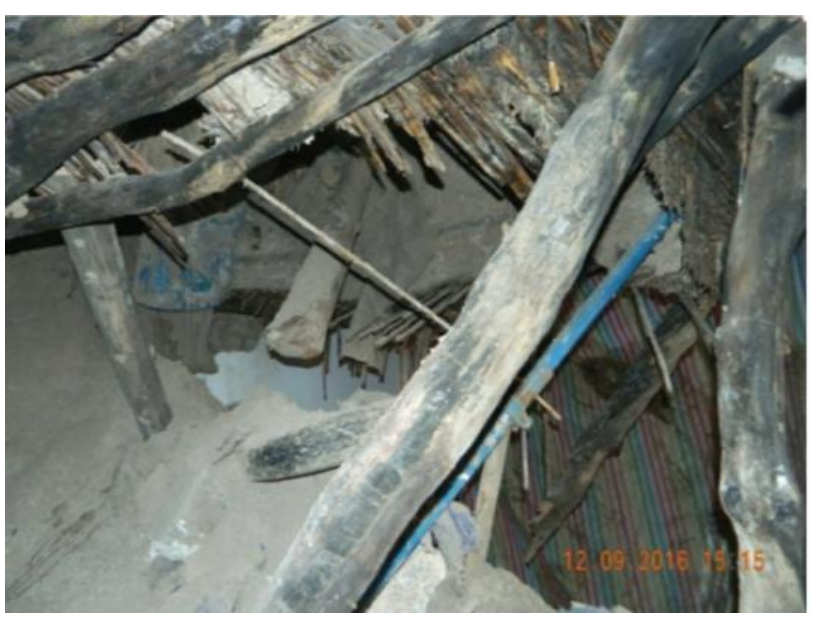

Pic 6

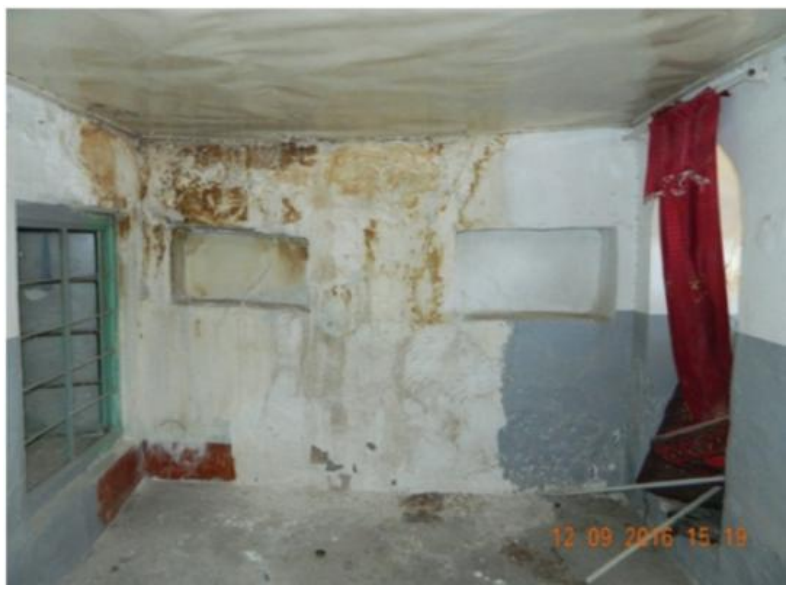

Pic 7

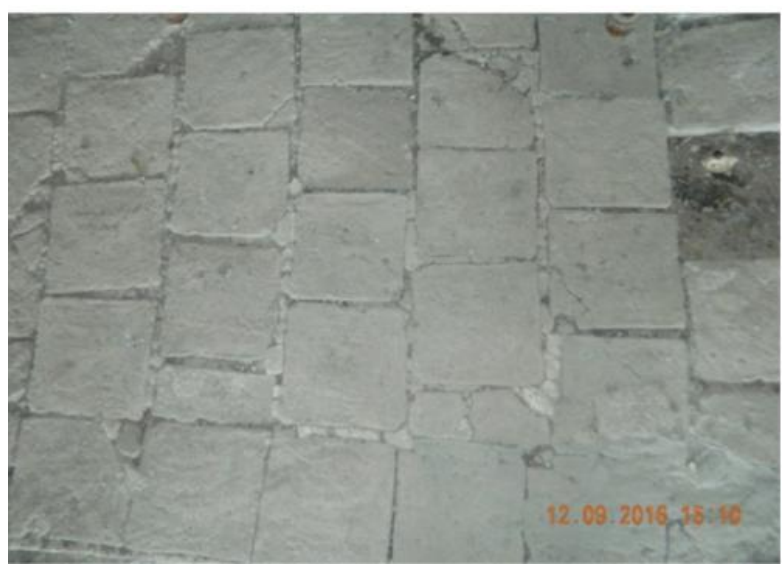

Pic 8

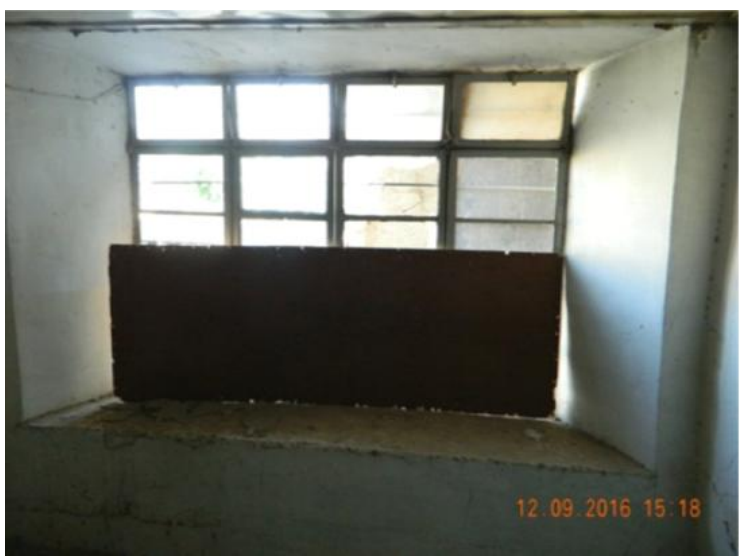

Pic 9

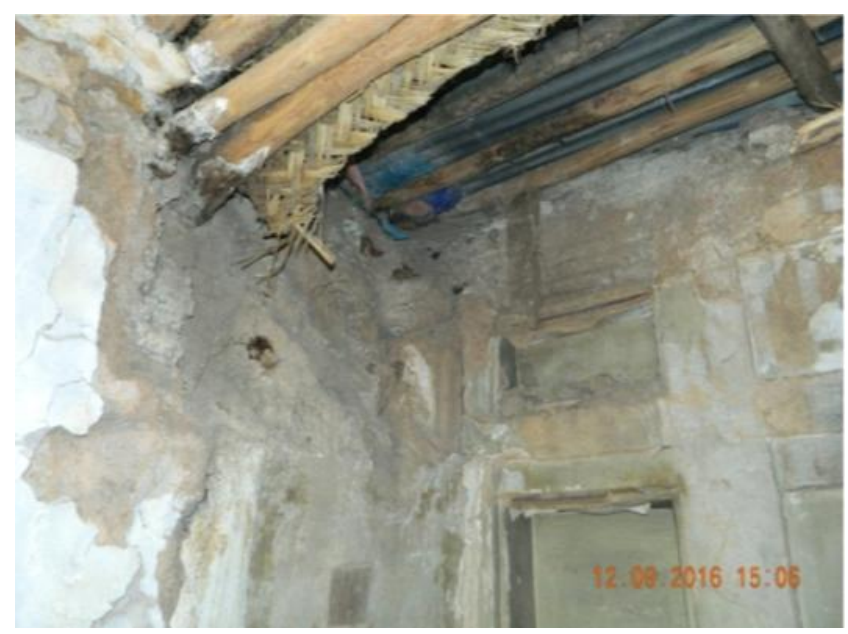

Pic 10

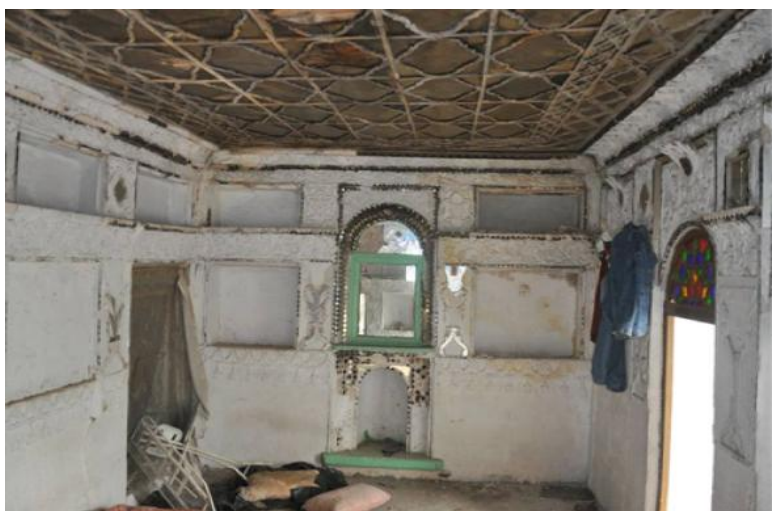

Pic 11

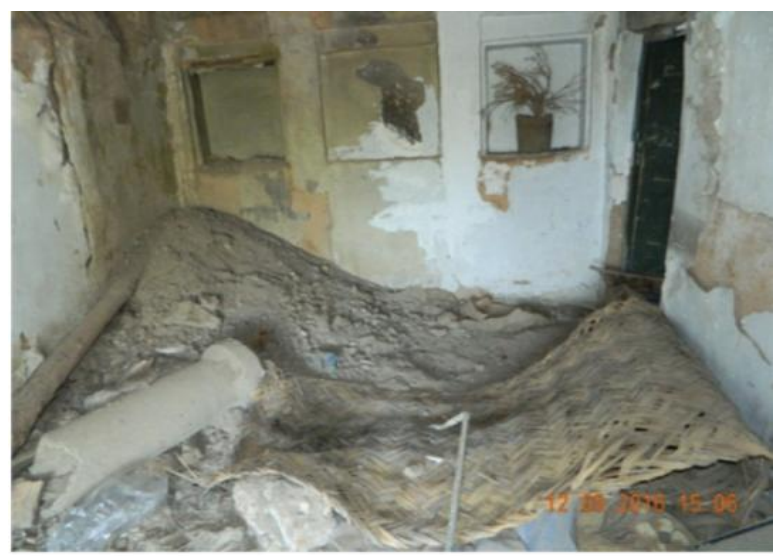

Pic 12

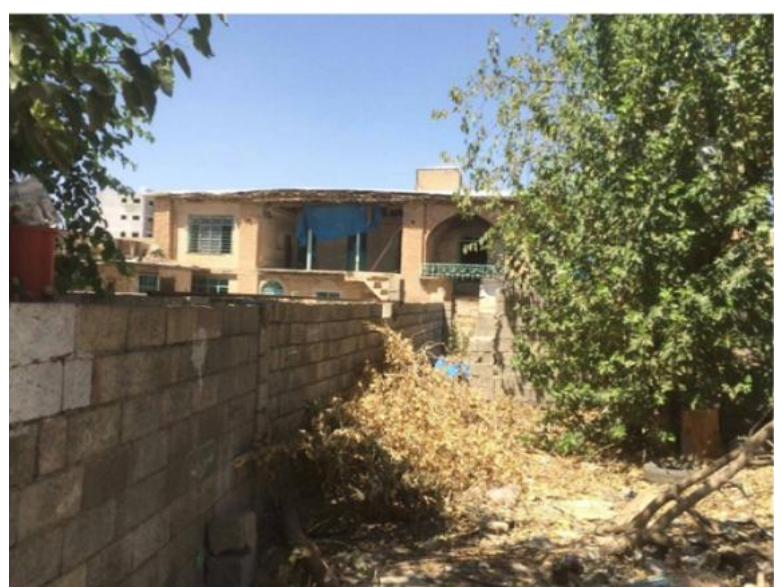

Pic 13

Volume 6 Issue 7, July 2017

www.ijsr.net

Licensed Under Creative Commons Attribution CC BY 
International Journal of Science and Research (IJSR)

ISSN (Online): 2319-7064

Index Copernicus Value (2015): 78.96 | Impact Factor (2015): 6.391

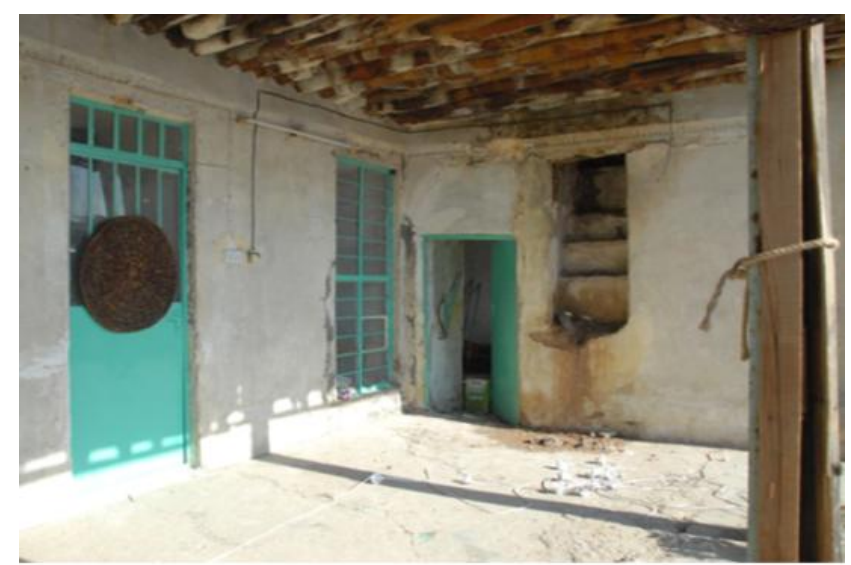

Pic 14

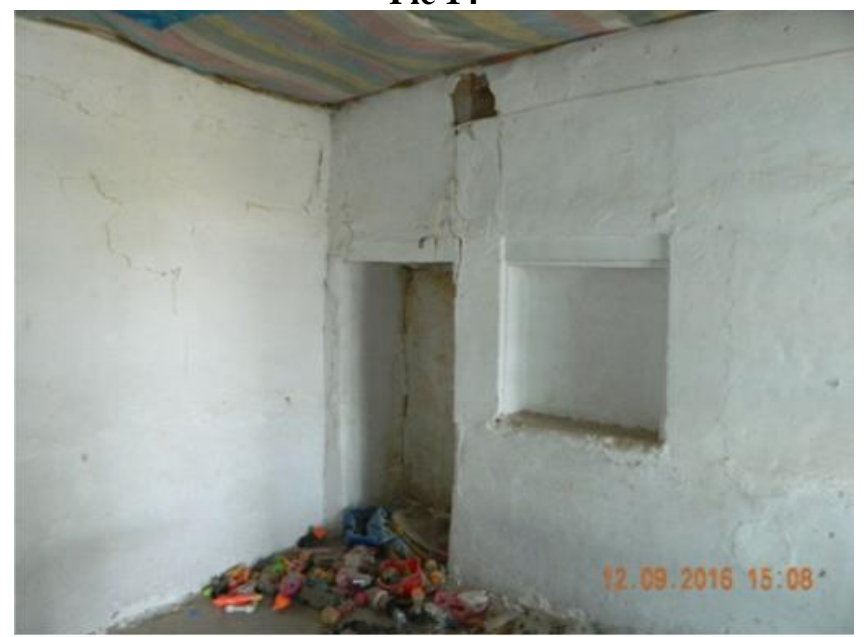

Pic 15

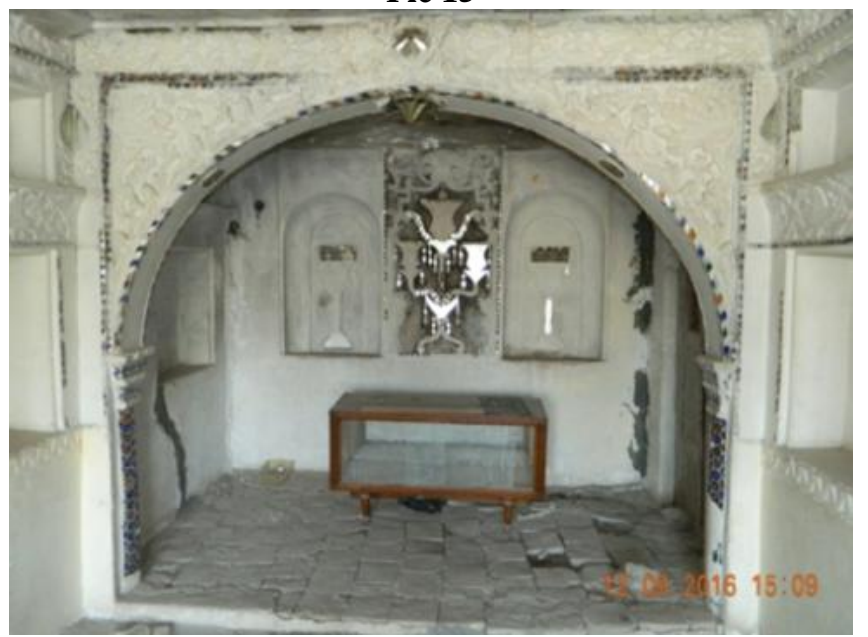

Pic 16
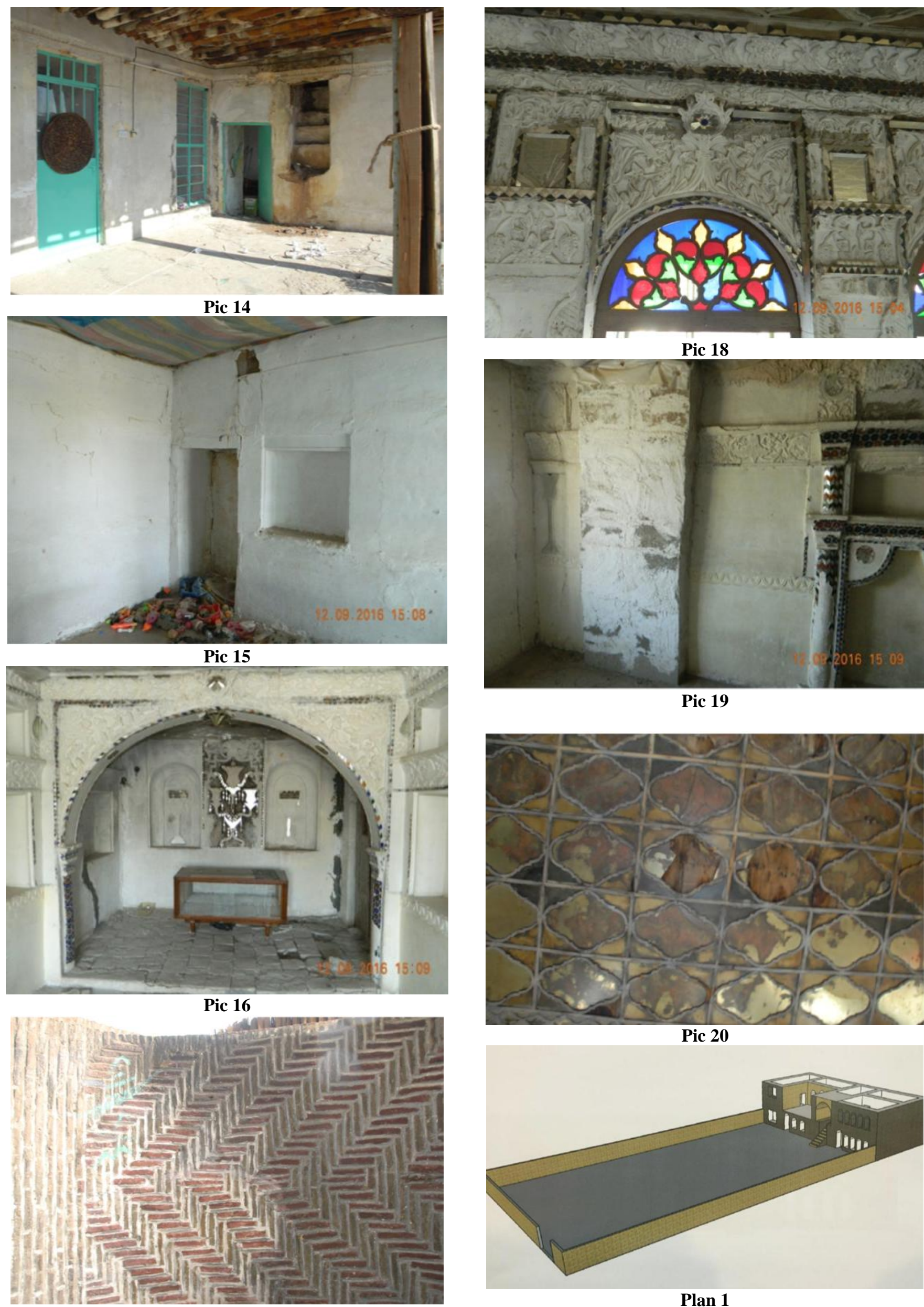

Pic 18

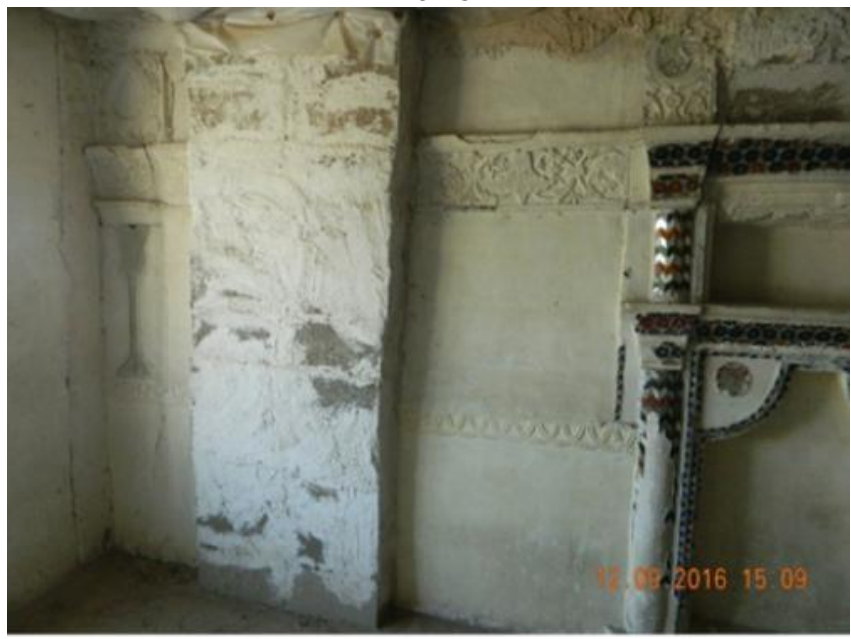

Pic 19

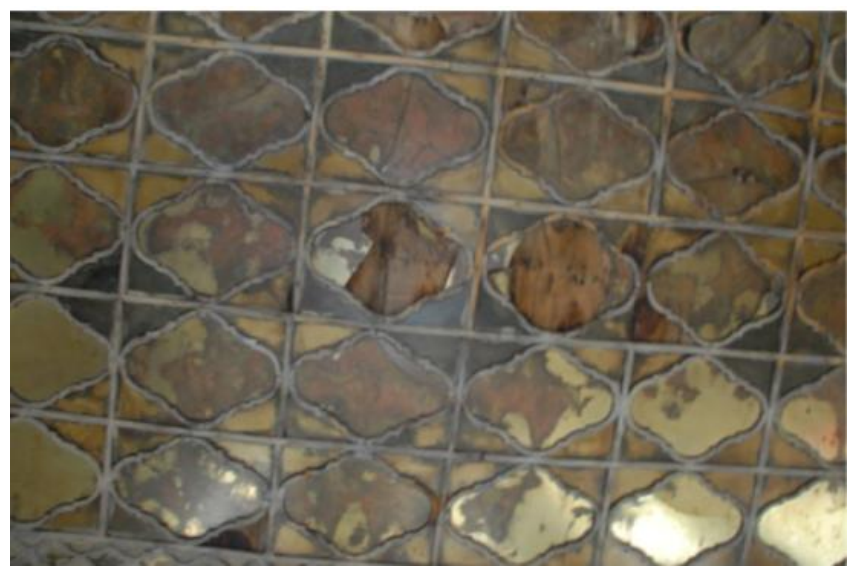

Pic 20

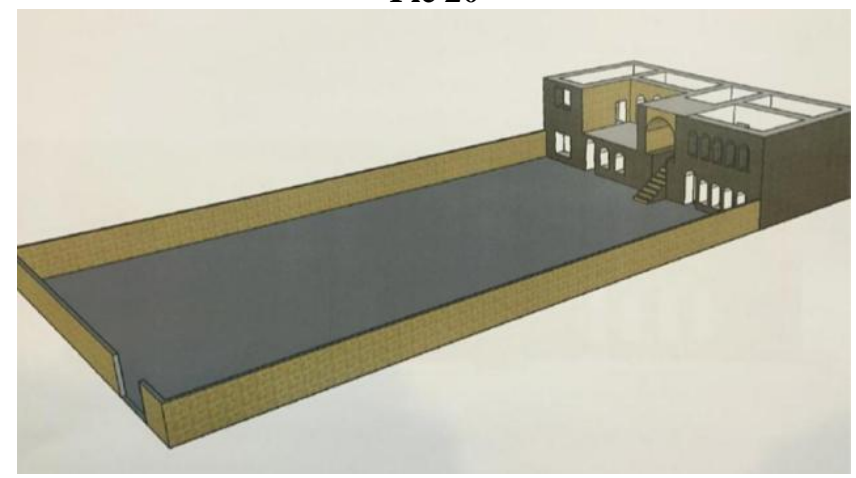

Plan 1

Pic 17

Volume 6 Issue 7, July 2017

www.ijsr.net

Licensed Under Creative Commons Attribution CC BY 
International Journal of Science and Research (IJSR)

ISSN (Online): 2319-7064

Index Copernicus Value (2015): 78.96 | Impact Factor (2015): 6.391

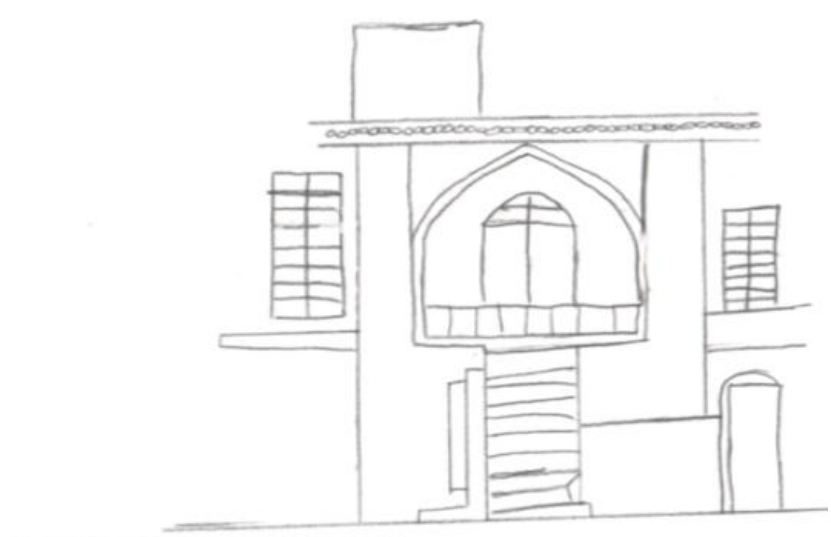

Plan 2
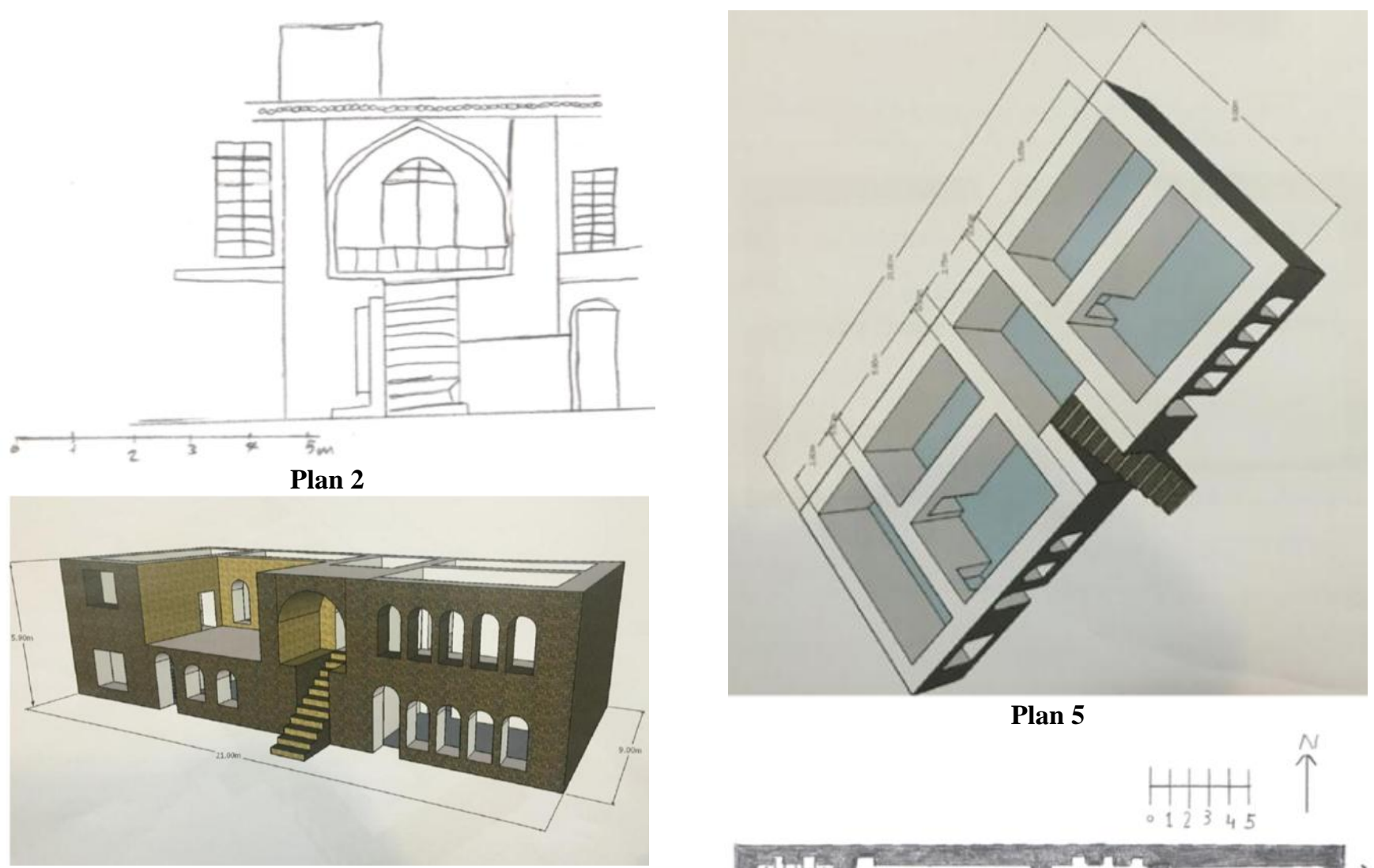

Plan 5
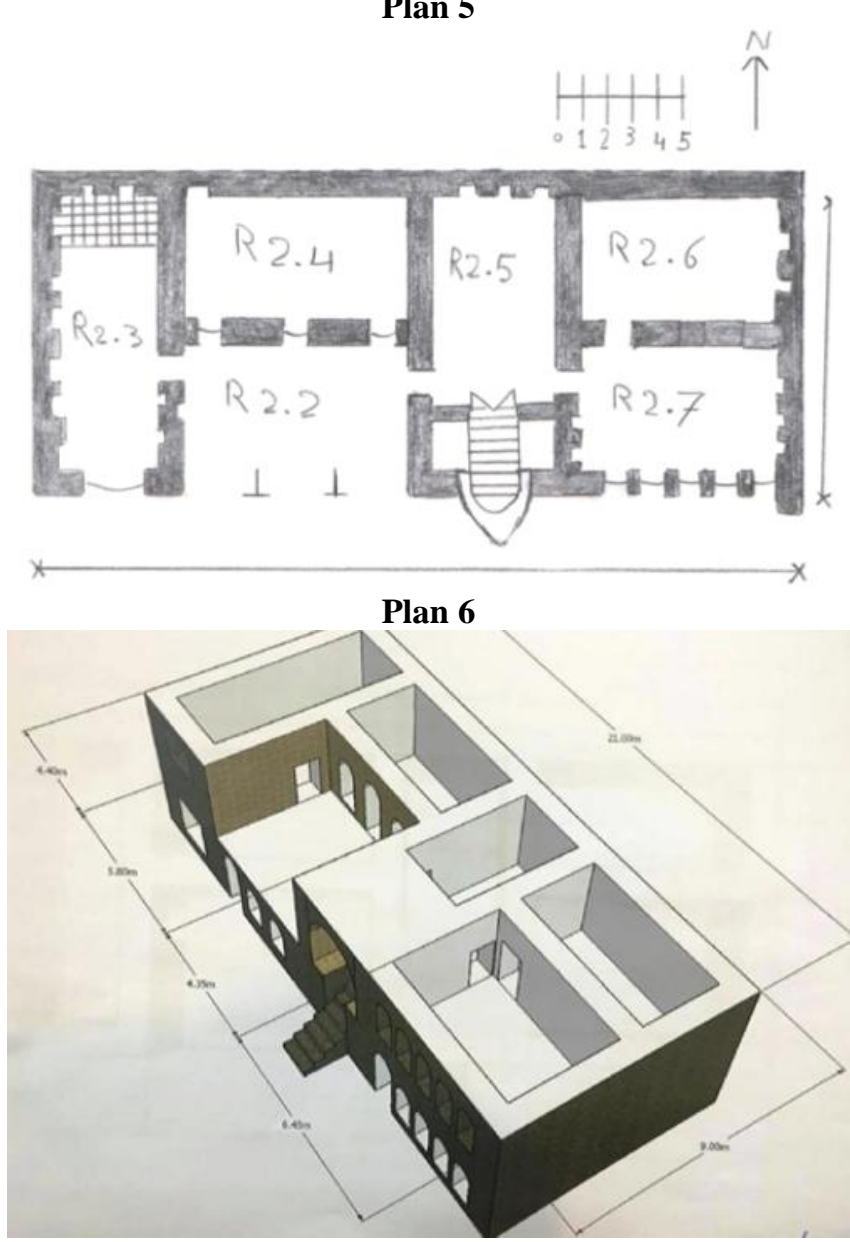

Plan 7

\section{Plan 4}

Volume 6 Issue 7, July 2017 www.ijsr.net

Licensed Under Creative Commons Attribution CC BY 


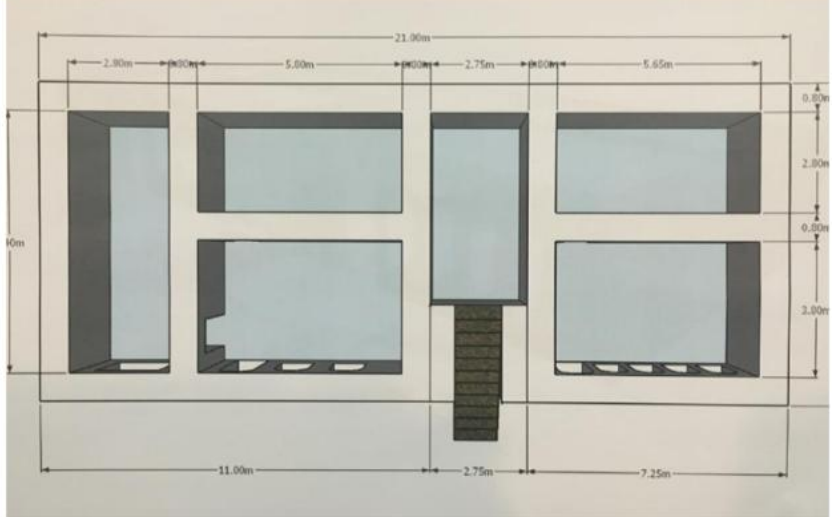

Plan 8

Volume 6 Issue 7, July 2017 www.ijsr.net

Licensed Under Creative Commons Attribution CC BY 